\title{
Pathological processes and therapeutic advances in radioiodide refractory thyroid cancer
}

\author{
Marika H Tesselaar', Johannes W Smit², James Nagarajah ${ }^{3}$, Romana T Netea-Maier ${ }^{2}$ \\ and Theo S Plantinga' \\ 1Department of Pathology, Radboud University Medical Center, Nijmegen, The Netherlands \\ IInternal Medicine, Division of Endocrinology Radboud University Medical Center, Nijmegen, The Netherlands \\ ${ }^{3}$ Radiology \& Nuclear Medicine, Radboud University Medical Center, Nijmegen, The Netherlands
}

Correspondence should be addressed to T S Plantinga Email theo.plantinga@ radboudumc.nl

\begin{abstract}
While in most patients with non-medullary thyroid cancer (TC), disease remission is achieved by thyroidectomy and ablation of tumor remnants by radioactive iodide (RAI), a substantial subgroup of patients with metastatic disease present tumor lesions that have acquired RAI resistance as a result of dedifferentiation. Although oncogenic mutations in $B R A F, T E R T$ promoter and TP53 are associated with an increased propensity for induction of dedifferentiation, the role of genetic and epigenetic aberrations and their effects on important intracellular signaling pathways is not yet fully elucidated. Also immune, metabolic, stemness and microRNA pathways have emerged as important determinants of TC dedifferentiation and RAI resistance. These signaling pathways have major clinical implications since their targeting could inhibit TC progression and could enable redifferentiation to restore RAI sensitivity. In this review, we discuss the current insights into the pathological processes conferring dedifferentiation and RAI resistance in TC and elaborate on novel advances in diagnostics and therapy to improve the clinical outcome of RAI-refractory TC patients.
\end{abstract}

\section{Introduction}

Non-medullary thyroid cancer (TC) is the most frequent endocrine tumor accounting for $90 \%$ of all endocrine cancer cases. Several histological TC subtypes are distinguished as papillary TC (PTC) as the most frequent, followed by follicular TC (FTC), invasive follicular-variant papillary TC and poorly differentiated TC and anaplastic TC (ATC) as the most rare subtypes (Xing 2013, Fagin \& Wells 2016). Patient prognosis is different for these TC subtypes; in most cases, PTC and FTC patients have a favorable prognosis after performing thyroidectomy and effective ablation of (metastatic) tumor remnants that have retained the capacity for iodide uptake and, hence, displayed high sensitivity to radioactive iodide (RAI) therapy. In contrast, poorly differentiated TC and ATC are often highly progressive, metastatic and resistant to RAI therapy at diagnosis due to loss of thyroid-specific gene expression. For the latter group of patients, treatment options are rarely curative and patients face an increased risk of death. While poorly differentiated TC patients with RAI-refractory tumor lesions have a variable prognosis depending on location and progression of metastases, ATC patients have a poor median survival of 5 months and a 1-year survival chance of less than 20\% (Smallridge et al. 2012, Cabanillas et al. 2016).

Published by Bioscientifica Ltd. 
Recently, studies into the molecular characteristics of TC have revealed genetic and transcriptomic hallmarks associated with the observed phenotypic differences between TC subtypes and have indicated that poorly differentiated TC and ATC originate from welldifferentiated tumors by the accumulation of additional genetic and epigenetic aberrations, resulting in the loss of thyroid-specific gene expression and development of resistance to RAI therapy. At the molecular level, this is corroborated by the Thyroid Differentiation Score (TDS), which consists of expression values of 16 thyroidspecific genes that stratify TC tumors based on their differentiation state. In ATC, the expression of virtually all TDS included genes is diminished, whereas in poorly differentiated TC, the human sodium iodide symporter (hNIS/SLC5A5) expression is specifically reduced and leaving expression of the other genes largely unaffected (Cancer Genome Atlas Research Network 2014, Landa et al. 2016, Yoo et al. 2016). In addition to genetic and epigenetic events that lead to a diminished expression of thyroid-specific genes, also immunometabolic networks, cancer stem cells (CSCs) and microRNAs (miRNAs) play a critical role in TC dedifferentiation resulting in aggressive and RAI-resistant TC with a poor clinical outcome. In this review, an integrated overview of the current knowledge on the role of these pathways in TC and future prospects for clinical implementation in personalized diagnostics and therapy are presented.

\section{Oncogenic pathways}

\section{Genetic factors}

It is well established that initial TC development is mostly caused by oncogenic hotspot mutations in the serine/ threonine-protein kinase $B R A F$, the intracellular signal transducer HRAS/KRAS/NRAS or genetic rearrangements of the tyrosine-protein kinase receptor RET proto-oncogene, which has culminated into the general concept of TC development driven by RAS-RAF-MEK-ERK and PI3K-AktmTOR oncogenic signaling pathways (Xing 2013, Petrulea et al. 2015). In addition, genome-wide association studies have uncovered several germline-encoded genetic variants that predispose to TC development, including the cancerassociated genes MAGI3, SMAD3 and TERT (Gudmundsson et al. 2012, 2017, Medici et al. 2014). Less well defined are the underlying mechanisms contributing to the transition from well differentiated to poorly differentiated TC or ATC. Mutations in BRAF, CTNNB1, TP53, EIF1AX, PTEN, PIK3CA, the SWI/SNF chromatin remodeling complex, mismatch repair genes and histone methyl transferases are frequently found in specifically poorly differentiated and ATC tumor subtypes, providing diagnostic markers and mechanistic insights into the dedifferentiation process (Garcia-Rostan et al. 1999, Hou et al. 2007, Santarpia et al . 2008, Nikiforov \& Nikiforova 2011). Furthermore, TERT promoter mutations are associated with more aggressive behavior and with RAI resistance (Melo et al. 2014, Landa et al. 2016, Liu et al. 2016, Yang et al. 2017).

\section{Epigenetic factors}

Because of their central role in RAI responsiveness, the regulation of hNIS, TSH receptor (TSHR), thyroglobulin (TG) and thyroid peroxidase (TPO) expression has been extensively investigated. Expression of these thyroidspecific genes is predominantly driven by thyroid-specific transcription factors NKX2-1 (TTF-1), FOXE1 (TTF-2), PAX8 and/or HHEX (Fernandez et al. 2015). However, despite the occurrence of TC dedifferentiation, the expression of these transcription factors remains largely unaltered, indicating that other intracellular aberrations are responsible for the diminished expression of hNIS, TSHR, TG and TPO. Accordingly, epigenetic mechanisms have been elucidated that influence the functional expression of thyroid-specific genes by modulation of DNA methylation or histone acetylation marks. In this respect, epigenetic modifications at the level of both DNA and histones are important regulators of gene expression; DNA methylation generally leads to gene silencing, whereas histone modifications modulate chromatin accessibility for binding of transcription factors. In previous studies, the role of DNA methylation in TC pathology and progression has been investigated. Several gene promoters and enhancers have been identified of which CpG islands are aberrantly methylated, such as PTEN, RAP1GAP and CITED1 (Alvarez-Nunez et al. 2006, Xing 2007, Zuo et al. 2010, Sassa et al. 2011). Furthermore, global DNA hypomethylation and specific DNA hypermethylation of several gene promoters and enhancers, including those driving expressions of hNIS, TSHR and tumor suppressor genes, have been observed in BRAF V600E-mutant PTCs and are associated with a silenced expression of the corresponding genes, resulting in less-differentiated tumor cells (Hu et al. 2006, Lee et al. 2008, Hou et al. 2011, Rodriguez-Rodero et al. 2013, Choi et al. 2014). These epigenetic changes could also lead to a dysregulated expression of pituitary tumor transforming gene (PTTG) and PTTG binding factor, factors that are known to repress hNIS expression, impair RAI uptake and to predict

Published by Bioscientifica Ltd. 
poor clinical outcome (Read et al. 2011, 2017). Moreover, histone deacetylase inhibitors have been demonstrated to elicit beneficial effects on hNIS expression and iodide uptake capacity in vitro, which however was not clinically validated (Hou et al. 2010, Zhang et al. 2014, Cheng et al. 2016, Nilubol et al. 2017). Despite these compelling findings, the clinical significance of DNA methylation of specific genes and modification of specific gene-associated histones remain to be investigated. Furthermore, since histone deacetylase inhibitors non-selectively influence histone marks of multiple genes, insights into genespecific histone (de)acetylation effects could provide explanations for the observed differences between in vitro models and patient studies and could revive the clinical potential of targeting gene-specific histone modifications.

\section{Transcriptional regulation by miRNAs}

miRNAs are a large array of short non-coding oligonucleotides that inhibit the gene expression at a posttranscriptional level by labeling target mRNA sequences for degradation, thereby influencing a large variety of biological pathways including apoptosis, proliferation and differentiation (Bartel 2004). Accumulating evidence indicates that miRNA expression profiles potently influence the cellular phenotype, both in physiological and pathological processes, and represents a promising therapeutic target for a wide range of malignancies (Rupaimoole \& Slack 2017). In TC, differences in miRNA expression profiles are associated with tumor histology and have emerged as potential biomarkers to distinguish between (1) PTC vs normal thyroid tissue (He et al. 2005, Pallante et al. 2006, Tetzlaff et al. 2007), (2) benign follicular adenoma versus malignant FTC (Rossing et al. 2012) and (3) classical FTC vs oncocyticvariant FTC (Nikiforova et al. 2008). Predominantly, the miRNAs miR-146b, miR-181b, miR-221, miR-222 and miR-224 are highly upregulated in PTC as compared to normal thyroid tissue (Agretti et al. 2012, Dettmer et al. 2013, Swierniak et al. 2013, Acibucu et al. 2014). In contrast, predictive miRNA biomarkers for FTC are upregulation of miR-181 and miR-200 and downregulation of miR-199 (Mancikova et al. 2015). Different miRNA expression profiles have been observed in ATC, with elevated expressions of miR-17, miR-221, miR-222 and decreased let-7, miR-30 and miR-29 expressions as compared to normal thyroid tissue (Mancikova et al.2015). Moreover, the differential expression of some of these and other miRNAs is associated with TC aggressiveness, epithelial-mesenchymal transition, vascular invasion, lymph node dissemination, risk of recurrence and dedifferentiation, including increased expression of miR-9, miR-21 and miR-146b, HMGB1-induced miR-221 and miR-222 upregulation and miR-204 downregulation (Braun et al. 2010, Mardente et al. 2012, Chou et al. 2013, Cancer Genome Atlas Research Network 2014, Guo et al. 2015, Sondermann et al. 2015). By specifically downregulating hNIS expression, miR-339 and miR-146b are identified to promote TC dedifferentiation and RAI resistance (Lakshmanan et al. 2015, Riesco-Eizaguirre et al. 2015). Accordingly, inhibition of these miRNAs by specific inhibitors results in improved RAI sensitivity (Lakshmanan et al. 2015, Li et al. 2015, Riesco-Eizaguirre et al. 2015). All together, miRNA dysregulation in TC provides mechanistic insights into TC development and progression and represents potential targets for improving TC diagnostics, prognosis and therapy.

In Fig. 1, a comprehensive overview of activated oncogenic pathways is provided which is involved in tumorigenesis, progression and RAI resistance of TC driven by genetic and epigenetic aberrations and by dysregulated expression of miRNAs and their target genes.

\section{Immunometabolic networks}

Despite the identification of genetic, epigenetic and miRNA aberrations that predispose to TC dedifferentiation and RAI refractoriness, still extensive heterogeneity exists within tumor subgroups regarding differentiation status and clinical RAI response. Hence, these factors only partially explain the occurrence of TC dedifferentiation and provide limited sensitivity and specificity to predict RAI responsiveness and clinical outcome. Other mechanisms involved in this phenomenon include the interaction of TC with its tumor microenvironment (TME). Within the TME of TC, tumor cells interact with immune cell infiltrates and orchestrate immune responses favoring tumor proliferation, dedifferentiation and progression (Galdiero et al. 2016, French et al. 2017). Some of the most abundant immune cells in TC are tumor-associated macrophages (TAMs). While in well-differentiated TC, only few TAMs are present, advanced TC tumors are heavily infiltrated by TAMs, which proportionally increases along the spectrum of dedifferentiation. Hence, the intratumoral density of TAMs is associated with poor prognosis (Ryder et al. 2008, Kim et al. 2013, 2016). Furthermore, inhibition of intratumoral TAM recruitment is shown to ameliorate TC progression, indicating the important functional role of TAMs in promoting TC aggressiveness (Ryder et al. 2013). Recently, by exploring the functional characteristics

Published by Bioscientifica Ltd. 


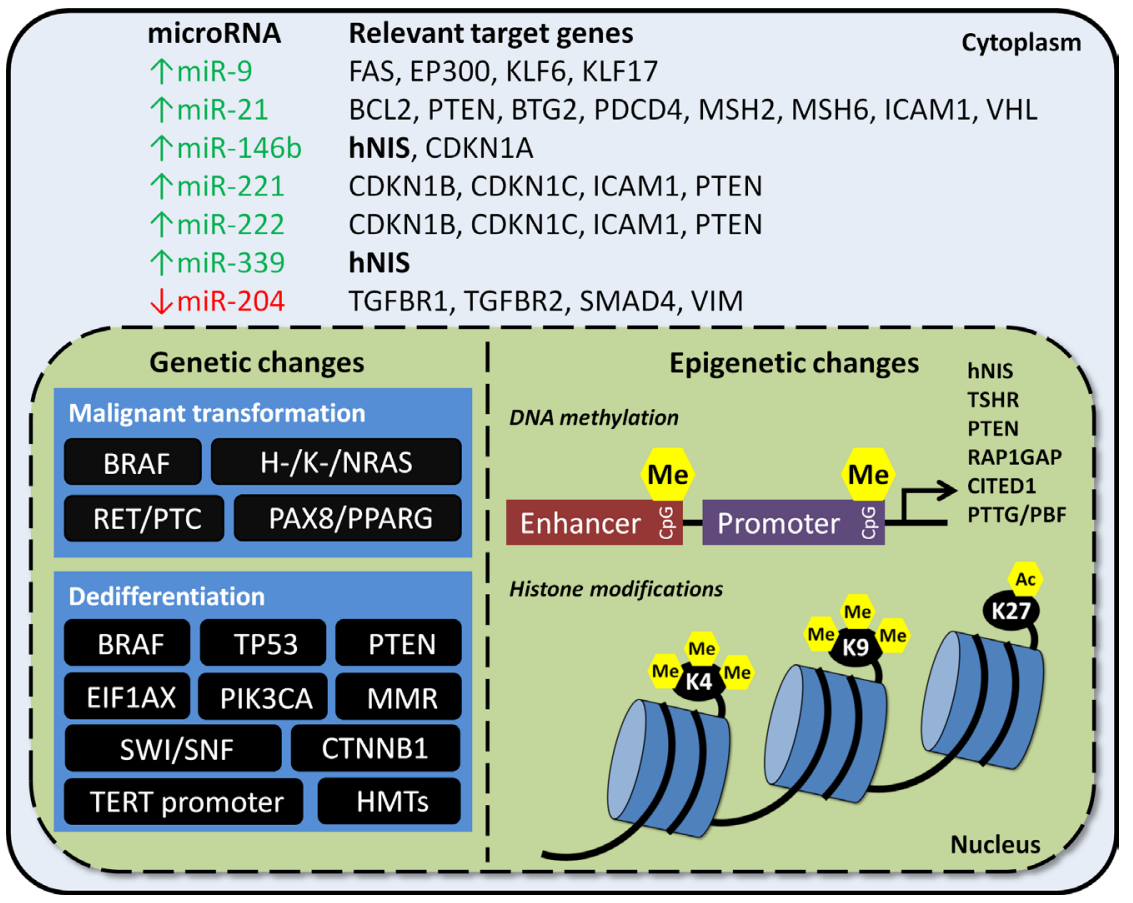

\section{Figure 1}

Schematic overview of activated oncogenic pathways involved in tumorigenesis, progression and radioactive iodide resistance in nonmedullary thyroid cancer driven by genetic and epigenetic aberrations and by dysregulated expression of microRNAs and their target genes. Genetic aberrations comprise point mutations and rearrangements in oncogenes and tumor suppressor genes and induce malignant transformation and/or dedifferentiation. Epigenetic aberrations include silencing of cancer-associated and thyroid-specific genes by DNA methylation and by modulation of histone acetylation or methylation of $\mathrm{H} 3 \mathrm{~K} 4, \mathrm{H} 3 \mathrm{~K} 9$ or $\mathrm{H} 3 \mathrm{~K} 27$ and other lysine residues of histones. Expression of several microRNAs is dysregulated in advanced thyroid cancer (upregulated microRNAs in green, downregulated microRNAs in red), leading to reciprocally regulated expression of their target genes. MMR, mismatch repair genes; HMTs, histone methyltransferases. of TAMs, it was observed that the glycolytic metabolite lactate is an important driver of the TAM pro-tumorigenic phenotype (Colegio et al. 2014, Arts et al. 2016). Lactate is a pleiotropic factor influencing many cancer-associated pathways of immune evasion, angiogenesis, invasiveness and dissemination (San-Millan \& Brooks 2017). Lactate concentrations are highly elevated in TC tumors because of aerobic glycolysis as a predominant metabolic pathway inside tumor cells. Aerobic glycolysis, also designated as the Warburg effect, has been established as a central and generic hallmark of malignant cells during proliferation, although under normoxic conditions, oxidative phosphorylation is reduced and, alternatively, cancer cells favor the oxygenindependent glycolysis pathway for fast generation of ATP and building blocks while reducing production of reactive oxygen species (Gatenby \& Gillies 2004, Hanahan \& Weinberg 2011, Lunt \& Vander Heiden 2011). Aerobic glycolysis is a specific feature of malignant cells and facilitates the activation of Hypoxia-Inducible Factor $1 \alpha$ (HIF-1 $\alpha)$ signaling, tumor growth, invasiveness and immune evasion in aggressive TC subtypes with lactate and HMGB1 as major intermediate factors (Koperek et al. 2013, Lee et al. 2015, Mardente et al. 2015, Gill et al. 2016). In turn, the HIF- $1 \alpha$ activity in tumor cells induces production and signaling of vascular endothelial growth factor (VEGF), facilitating angiogenesis and activation of effector mechanisms further promoting invasion, metastatic potential and dedifferentiation of TC (de Araujo-Filho et al. 2009, Karaca et al. 2011, Galdiero et al. 2016).
In addition, also other immunomodulatory factors are demonstrated to be involved in aggressiveness and RAI sensitivity of TC. One of these factors is the NF- $\kappa$ B pathway, of which genetic variation in the NF- $\kappa \mathrm{B}$ inhibitor alpha (NFKBIA) gene is associated with decreased sensitivity to RAI therapy and with elevated production of interleukin (IL-)1 $\beta$ (Plantinga et al. 2017). Interestingly, IL-1 $\beta$ has been demonstrated to decrease hNIS and TG expression in thyrocytes and TC cell lines (Yamashita et al. 1989, Kimura et al. 1992, Ohta et al. 1996). Another pro-inflammatory protein involved in TC dedifferentiation is IL-32, which activates pro-survival pathways driven by IL-8 (Heinhuis et al. 2016). Accordingly, inhibition of IL-8 signaling results in decreased survival and proliferation of TC tumor cells in vitro and in vivo (Liotti et al. 2017). Furthermore, genetic variation in IL32, leading to an elevated expression of the IL-32 $\gamma$ isoform and increased production of the proinflammatory cytokines TNF $\alpha$, IL- $1 \beta$ and IL-6, contributes to susceptibility to TC development and RAI resistance (Plantinga et al. 2013).

These findings corroborate the biological connection between the role of aerobic glycolysis and HIF- $1 \alpha$ signaling in TC tumor cells on the one hand with infiltration of macrophages that consequently acquire pro-tumorigenic features on the other. Based on this extensive body of evidence, the interplay between tumor cells and TAMs has emerged as an important mechanism in RAI resistance and poor clinical outcome of TC patients, as illustrated in Fig. 2 (Scarpino et al. 2004, Ryder et al. 2008,

Published by Bioscientifica Ltd 


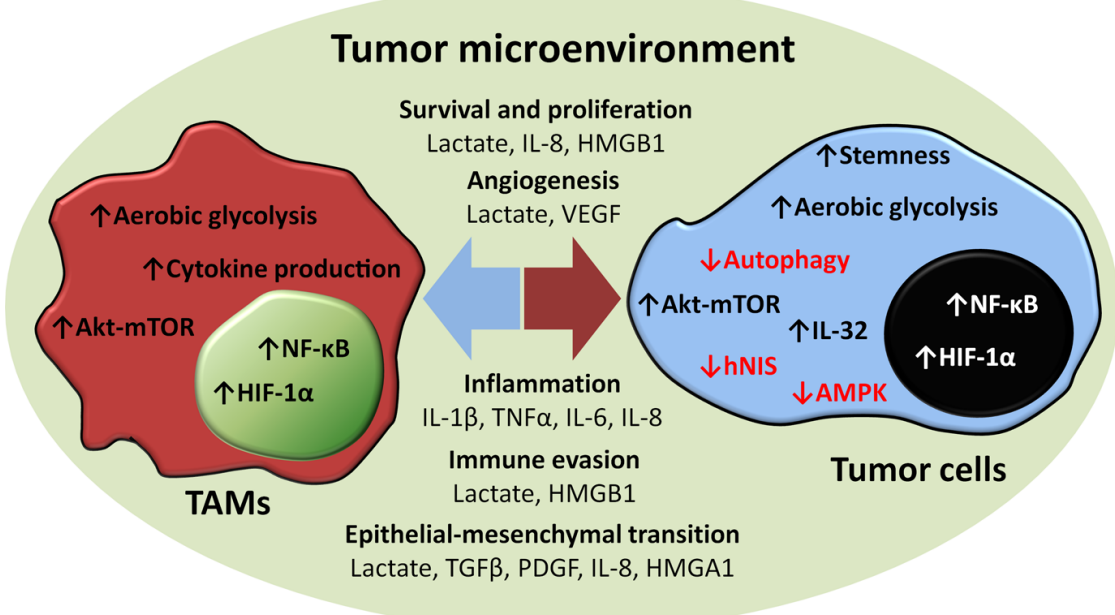

\begin{abstract}
Figure 2
Schematic overview of interconnected immunometabolic pathways elicited in tumor cells and tumor-associated macrophages (TAMs) in the tumor microenvironment of radioiodide refractory thyroid cancer that collectively promote tumor initiation, progression and dedifferentiation. Soluble factors produced by either tumor cells and/or TAMs activate intracellular pathways that contribute to proliferation, angiogenesis, pro-tumorigenic inflammation, immune evasion and epithelialmesenchymal transition of non-medullary thyroid cancer.
\end{abstract}

Burrows et al. 2010, Klaus et al. 2017). Future studies are warranted to identify appropriate targets for therapy to counteract the pro-tumorigenic intercellular interactions between tumor cells and TAMs.

It is also well established that several other specialized immune cell types are present in TC tumors, including dendritic cells, myeloid-derived suppressor cells, natural killer cells and regulatory T-cells that express inhibitory immune checkpoints such as Programmed cell death protein 1 (PD-1) or Programmed death-ligand 1 (PD-L1) (extensively reviewed in French et al. (2017)). Although elevated numbers of these cell types are observed either in the TME or in peripheral blood of TC patients, their clinical significance and their contribution to TC dedifferentiation and RAI resistance still remain unexplored.

\section{Autophagy}

Another mechanism involved in TC dedifferentiation is autophagy, an intracellular degradation machinery influencing survival, proliferation and differentiation pathways (Bincoletto et al. 2013, Netea-Maier et al. 2015). Autophagy is a central process downstream of both PI3K-Akt-mTOR and BRAF-RAS-MEK-ERK oncogenic signaling and is therefore strongly implicated in thyroid carcinogenesis, proliferation and dedifferentiation. In physiology, autophagy facilitates intracellular degradation of cytoplasmic components, including organelles and large protein complexes, in order to maintain cellular homeostasis and to generate energy and building blocks for protein synthesis (Mizushima \& Komatsu 2011, Feng et al. 2015). In cancer, autophagy is known as a doubleedged sword with both cancer-promoting and cancerinhibiting features. By its role as a survival mechanism in hypoxic, nutrient-deprived or otherwise threatening conditions, autophagy promotes resistance to chemo- and radiotherapy. In contrast, beneficial effects of autophagydriven survival are rendered by potent inhibition of cell proliferation, thereby blocking tumor growth (Gewirtz 2014, Duffy et al. 2015, Kumar et al. 2015). In addition to effects on survival and proliferation, autophagy is also involved in cellular differentiation (Mizushima \& Levine 2010, Helgason et al. 2013). In TC specifically, autophagy has been shown to intertwine with oncogenic signaling and in vitro activation of autophagy is demonstrated to increase sensitivity of TC to treatment with chemotherapy, radiotherapy, TRAIL and mTOR kinase inhibitors (Lin et al. 2010, Jin et al. 2014, Morani et al. 2014, Yi et al. 2014, Fan et al. 2015, Plews et al. 2015) and to promote resistance to BRAF inhibitors (Wang et al. 2017). Furthermore, germline-genetic variants in autophagy genes, specifically ATG5 (rs2245214) and ATG16L1 p.Thr300Ala (rs2241880), known to functionally impair the autophagy machinery, are associated with genetic susceptibility to TC development and/or resistance to RAI treatment (Huijbers et al. 2012, Plantinga et al. 2014b). Accordingly, loss of autophagy activity was demonstrated to be associated with RAI resistance in TC patients (Plantinga et al. 2016). These findings indicate the important role of autophagy in the regulation of TC proliferation and differentiation.

\section{Epithelial-mesenchymal transition (EMT)}

One of the mechanisms that enables epithelial cellderived tumor cells to invade other tissues and to establish lymphatic or hematogenous metastases is EMT. By this process, tumor cells gain mesenchymal properties including enhanced migration, invasiveness and elevated

Published by Bioscientifica Ltd. 
resistance to anoikis and apoptosis and display augmented production of extracellular matrix components (Vasko et al. 2007, Kalluri \& Weinberg 2009). EMT occurring in TC and other epithelial cell-derived tumors, designated as type III EMT, is considered to be elicited by similar genetic and epigenetic changes that also drive primary tumor development (Knauf et al. 2011, Baquero et al. 2013, Mitchell et al. 2016, Anelli et al. 2017). In addition, EMT is often accompanied by dedifferentiation and gain of stem cell properties, representing another cause of acquired RAI resistance of metastatic TC lesions in lymph nodes and at distal locations (Riesco-Eizaguirre et al. 2009, Liu \& Brown 2010, Hardin et al. 2013, Lan et al. 2013). Once tumor cells have achieved colonization at the metastatic location, tumor cells reverse EMT by mesenchymalepithelial transition (MET), explaining the resemblance of morphological characteristics shared with the primary tumor. Despite the transition of metastatic tumor lesions to the original tumor cell phenotype by MET, the loss of differentiation markers is considered irreversible resulting in RAI-refractory metastases. Molecular pathways driving EMT in TC involve zinc finger E-box binding homeobox 1 (ZEB1), Smad7 and Slug and loss of E-cadherin expression is shown to predominantly occur in metastatic PTC and ATC tissues (Montemayor-Garcia et al. 2013, Wang et al. 2013, 2014, Guo et al. 2014, Jung et al. 2015, Li et al. 2016). Important growth factors promoting EMT in TC are transforming growth factor $\beta$ (TGF- $\beta$ ) and platelet-derived growth factor (PDGF), which are demonstrated to activate the expression of vimentin, Slug, Snail, Twist, PRRX1, High Mobility Group A1 (HMGA1), HMGB1 and the stem cell marker SOX9 and to inhibit E-cadherin and hNIS, leading to enhanced dedifferentiation and increased in vivo tumor growth and spread (Costamagna et al. 2004, Mardente et al. 2012, Hardin et al. 2014, Baquero et al. 2016, EkpeAdewuyi et al. 2016, Lv et al. 2016, Huang \& Guo 2017, Zhong et al. 2017). HIF-1 $\alpha$ signaling and inflammatory mediators are demonstrated to evoke the expression of EMT markers in TC ( $\mathrm{Lv}$ et al. 2015, Yang et al. 2015, Klaus et al. 2017). Moreover, previous studies indicate that abrogation of autophagy in TC is an important mechanism contributing to EMT induction, which is counteracted by activation of the AMPK-autophagy pathway (Han et al. 2015, Cazarin et al. 2016, Gugnoni et al. 2017). In addition to EMT occurring in tumor cells intrinsically, surrounding cells in the TME also contribute to EMT induction in TC. Tumor-infiltrating mast cells have been demonstrated to promote TC aggressiveness by increasing proliferation, invasiveness and vascularization as a result of EMT induction by signaling through IL-8,
Akt and Slug (Melillo et al. 2010, Visciano et al. 2015). All together, these findings illustrate an interconnected signaling network of pathways driving angiogenesis, tumor cell survival, proliferation, dedifferentiation and EMT, thereby evoking invasion, dissemination and RAI resistance of TC tumors (illustrated in Fig. 2).

\section{CSCs}

The thyroid gland is capable of regenerating itself, at least to some extent, which is thought to be facilitated by stem or progenitor cells present inside the adult gland located in a niche designated as solid cell nests (Coclet et al. 1989, Gibelli et al. 2009). Thyroid stem cells are characterized by the expression of p63, Oct-4, hNanog, CD44 and SCA-1 and are able to differentiate into fully functional thyroid follicular cells (Hoshi et al. 2007, Lan et al. 2007, Klonisch et al. 2009, Ahn et al. 2014). Also, the expression of the stem cell marker aldehyde dehydrogenase together with enhanced cell proliferation and invasion is observed in small populations of tumor cells in PTC, FTC and ATC (Todaro et al. 2010). Therefore, an alternative hypothesis of the etiology of poorly differentiated TC and ATC, opposed to gradual loss of differentiation in pre-existing PTC or FTC by accumulation of additional genetic aberrations, is malignant transformation of thyroid stem or precursor cells into CSCs (Takano \& Amino 2005, Zhang et al. 2006, Takano 2014). In this scenario, specifically thyroid stem or precursor cells acquire genetic and epigenetic aberrations and initiate tumor development. This hypothesis has been especially postulated as a potential origin of ATC. However, this could also explain the occurrence of poorly differentiated TC originating from thyroid precursor cells, including thyroblasts or prothyrocytes (Hoshi et al. 2007, Lan et al. 2007, Fagman \& Nilsson 2011, Zane et al. 2016). This is supported by the striking resemblance between thyroid-specific gene expression profiles of well-differentiated TC, poorly differentiated TC and ATC on the one hand and end-stage differentiated thyroid follicles, thyroid precursor and thyroid progenitor cells on the other. Fully differentiated follicular cells and welldifferentiated TC exhibit the physiological expression of TG, TPO and hNIS, whereas thyroid stem cells, poorly differentiated TC and ATC are all characterized by the lack of end-stage differentiation markers (Takano 2014, Landa et al. 2016). To improve diagnostics and therapy for TC patients with tumors driven by CSCs, validation of specific biomarkers and further insights into the pathological mechanisms of TC development, progression and RAI resistance elicited by thyroid CSCs are warranted.

Published by Bioscientifica Ltd. 


\section{Emerging treatments for RAI-refractory TC}

Since RAI-refractory TC also displays diminished susceptibility to other conventional anticancer treatments, i.e. chemo- and radiotherapy, treatment options are limited (Pacini et al. 2012, De Bernardi et al. 2014, Romesser et al. 2014). Over the last decades, adjunctive therapies have been investigated with the purpose to restore RAI sensitivity in poorly differentiated $\mathrm{TC}$, termed as redifferentiation. Initially, these were vitamin A derivatives (retinoic acid, bexarotene), PPAR $\gamma$ activators (thiazolidinediones), inhibitors of iodide release (lithium) and histone deacetylase inhibitors (valproic acid, depsipeptide, trichostatin $\mathrm{A}$ ), which, however, were minimally effective in clinical trials (Liu et al. 2006, 2008, Kim et al. 2009, Rosenbaum-Krumme et al. 2012a,b, Nilubol et al. 2017). More recently, kinase inhibitors have been demonstrated to be more effective, with inhibitors of BRAF and MEK kinases in combination with RAI treatment reaching temporarily improved clinical responses in $40-60 \%$ of RAI-refractory TC patients. Furthermore, two other targets have been identified to induce effective redifferentiation in vitro: inhibition of the mTOR kinase and activation of autophagy and cFOS by $\mathrm{Na}^{+} / \mathrm{K}^{+}$ATPase inhibitors (Plantinga et al. 2014a, Tesselaar et al. 2017). The currently available evidence of these emerging redifferentiation therapies is summarized in Table 1.

\section{MEK inhibition}

For over a decade, MEK kinase inhibitors have been regarded as an important target for treating RAI-resistant TC. Numerous in vitro and in vivo mouse studies have shown the capacity of these agents to inhibit tumor progression and to augment thyroid-specific gene expression (Fenton et al. 2010, Henderson et al. 2010, Chakravarty et al. 2011, Nagarajah et al. 2016). In the clinical setting, the MEK inhibitor selumetinib was observed to profoundly increase RAI avidity in metastatic poorly differentiated $\mathrm{TC}$, resulting in increased iodide accumulation in target lesions in 12 out of 20 patients and reaching a clinical response rate in eight of these patients (Ho et al. 2013). Recently, a phase III clinical trial (ClinicalTrials.gov number, NCT01843062) is initiated to validate these beneficial effects of adjunctive selumetinib treatment in a larger cohort of RAI-refractory TC patients.

\section{BRAF inhibition}

The V600E hotspot mutation in the BRAF oncogene has been well established as an oncogenic driver of PTC. As a targeted treatment, small molecules have been developed and experimentally tested that specifically inhibit the V600E-mutated BRAF kinase, including sorafenib, vemurafenib and dabrafenib (Liu et al. 2012). Currently, sorafenib (simultaneously inhibiting V600E mutant BRAF, VEGFR and PDGFR) and lenvatinib (multiple kinase inhibitor of VEGFR, FGFR, PDGFR, c-Kit and RET) are approved for treatment of RAI-refractory TC patients (Brose et al. 2014). Despite its specificity for V600E mutant $B R A F$, sorafenib appears equally effective for treatment of advanced BRAF wild-type PTC, questioning the contribution of V600E mutant BRAF inhibition to the observed clinical effects of sorafenib. In another clinical trial, benefits of vemurafenib treatment for RAI-refractory TC patients were studied, which was shown to establish partial responses in $38.5 \%$ of the patients without administration of additional RAI treatments (Brose et al. 2016). In addition, the redifferentiation potential of the BRAF V600E inhibitors vemurafenib and dabrafenib has been assessed in RAI-refractory TC patients. Strikingly, out of ten treated patients with dabrafenib in combination with RAI, six patients exhibited increased intratumoral iodide accumulation resulting in either partial response or stable disease (Rothenberg et al. 2015). Another study reported one single PTC patient with metastatic disease that reached a complete response by treatment with vemurafenib followed by RAI (Huillard et al. 2016). In contrast, no increased iodide avidity was reached with sorafenib treatment (Hoftijzer et al. 2009). The potential

Table 1 Overview of currently available evidence on emerging non-medullary thyroid cancer redifferentiation therapies.

\begin{tabular}{|c|c|c|c|}
\hline \multirow[b]{2}{*}{ Therapeutic target } & \multirow[b]{2}{*}{ Drug name } & \multicolumn{2}{|c|}{ Preclinical data } \\
\hline & & In vitro & In vivo \\
\hline MEK & Selumetinib & $\mathrm{X}$ & $\mathrm{X}$ \\
\hline \multirow[t]{2}{*}{ BRAF } & Dabrafenib & $X$ & $X$ \\
\hline & Vemurafenib & $X$ & $x$ \\
\hline mTOR & Everolimus & $X$ & - \\
\hline Autophagy & Digoxin & $X$ & - \\
\hline
\end{tabular}

\begin{tabular}{|c|c|c|c|}
\hline \multicolumn{4}{|c|}{ Clinical response rates } \\
\hline PD (\%) & SD (\%) & PR (\%) & CR (\%) \\
\hline 0 & 37.5 & 62.5 & 0 \\
\hline 10 & 70 & 20 & 0 \\
\hline \multicolumn{4}{|c|}{ Single case study, CR was reached } \\
\hline- & - & - & - \\
\hline- & - & - & - \\
\hline
\end{tabular}

CR, complete response; PD, progressive disease; PR, partial response; SD, stable disease.

http://jme.endocrinology-journals.org DOI: 10.1530/JME-17-0134
๑ 2017 Society for Endocrinology Printed in Great Britain
Published by Bioscientifica Ltd 
of lenvatinib to establish TC redifferentiation in RAIrefractory TC patients has not been investigated so far.

Notably, not all RAI-refractory TC patients benefit from the above-mentioned adjunctive treatments for improving RAI response, indicating that between patients, clinically significant phenotypic differences exist that are decisive for treatment response. Additional efforts are therefore warranted to characterize tumor-associated factors that counteract or disable TC redifferentiation in order to further optimize the clinical efficacy of these targeted therapies.

\section{mTOR inhibition}

The mTOR (mammalian target of rapamycin) kinase is an important factor in oncogenic signaling downstream of PI3K and Akt, one of the pathways heavily implicated in TC pathogenesis (Netea-Maier et al. 2015, Petrulea et al. 2015). Inhibitors of mTOR have been developed that are demonstrated to ameliorate tumor growth in a number of malignancies. In TC specifically, the mTOR inhibitor rapamycin was observed to restore hNIS expression and iodide uptake capacity in vitro in TC cell lines (Plantinga et al. 2014a). Clinically, treatment with the mTOR inhibitor everolimus or temsirolimus, alone or in combination with sorafenib, has been shown to result in stable disease in about $50 \%$ of the TC patients with advanced disease and, rarely, in partial responses without reaching complete responses (Lim et al. 2013, Wagle et al. 2014, Schneider et al. 2017, Sherman et al. 2017). Unfortunately, a potentially increased RAI avidity induced in patient tumors by treatment with mTOR inhibitors has not been investigated in these trials.

\section{Autophagy activation}

The functional role of autophagy in RAI resistance was investigated by assessing the capacity to increase RAI sensitivity by treatment with autophagy-activating drugs. By testing five different classes of autophagy activators, it was demonstrated that $\mathrm{Na}^{+} / \mathrm{K}^{+}$ATPase inhibitors such as digoxin, also designated as digitalis-like compounds or cardiac glycosides, are capable of restoring hNIS expression and iodide uptake in TC cell lines (Tesselaar et al. 2017). Interestingly, in other cancer types, these agents have been shown to inhibit other mechanisms that are also involved in TC aggressiveness and RAI resistance, including aerobic glycolysis, TERT activity, EMT, angiogenesis and growth factor signaling, indicating its multifaceted effects as promisinganticancertreatment(Prassas \& Diamandis 2008).
Future studies in mouse models and TC patients are required for assessing the clinical utility of digoxin and its analogs as adjunctive treatment to improve RAI sensitivity in TC.

\section{Concluding remarks}

Although non-medullary TC patients generally have a good prognosis and a high propensity to reach long-term remission, high-quality diagnostics and effective treatment options for patients with metastatic RAI-refractory TC are still lacking leading to high morbidity and mortality rates in this subset of patients. Recent advances in understanding the underlying mechanisms of TC dedifferentiation and RAI resistance have generated the required insights into the identification of novel clinically relevant biomarkers and therapeutic targets, especially MEK, BRAF and mTOR kinases and autophagy that harbor the promising potential to achieve effective patient-tailored diagnosis and therapy of RAI-refractory TC.

\section{Declaration of interest}

The authors declare that no conflict of interest exists that could be perceived as prejudicing the impartiality of this review.

\section{Funding}

T S Plantinga was supported by a Veni grant of the Netherlands Organization for Scientific Research (NWO; grant number 016.136.065) and by the Alpe d'HuZes fund of the Dutch Cancer Society (grant number KUN2014-6728). R T Netea-Maier was supported by a grant from the Dutch Cancer Society (grant number \#10559).

\section{References}

Acibucu F, Dokmetas HS, Tutar Y, Elagoz S \& Kilicli F 2014 Correlations between the expression levels of micro-RNA146b, 221, 222 and p27Kip1 protein mRNA and the clinicopathologic parameters in papillary thyroid cancers. Experimental and Clinical Endocrinology and Diabetes 122 137-143. (doi:10.1055/s-0034-1367025)

Agretti P, Ferrarini E, Rago T, Candelieri A, De Marco G, Dimida A, Niccolai F, Molinaro A, Di Coscio G, Pinchera A, et al. 2012 MicroRNA expression profile helps to distinguish benign nodules from papillary thyroid carcinomas starting from cells of fine-needle aspiration. European Journal of Endocrinology 167 393-400. (doi:10.1530/EJE-12-0400)

Ahn SH, Henderson YC, Williams MD, Lai SY \& Clayman GL 2014 Detection of thyroid cancer stem cells in papillary thyroid carcinoma. Journal of Clinical Endocrinology and Metabolism 99 536-544. (doi:10.1210/jc.2013-2558)

Alvarez-Nunez F, Bussaglia E, Mauricio D, Ybarra J, Vilar M, Lerma E, de Leiva A, Matias-Guiu X \& Thyroid Neoplasia Study Group 2006 PTEN promoter methylation in sporadic thyroid carcinomas. Thyroid 16 17-23. (doi:10.1089/thy.2006.16.17)

Anelli V, Villefranc JA, Chhangawala S, Martinez-McFaline R, Riva E, Nguyen A, Verma A, Bareja R, Chen Z, Scognamiglio T, et al. 2017 
Oncogenic BRAF disrupts thyroid morphogenesis and function via twist expression. eLife 6 e20728. (doi:10.7554/eLife.20728)

Arts RJ, Plantinga TS, Tuit S, Ulas T, Heinhuis B, Tesselaar M, Sloot Y, Adema GJ, Joosten LA, Smit JW, et al. 2016 Transcriptional and metabolic reprogramming induce an inflammatory phenotype in non-medullary thyroid carcinoma-induced macrophages. Oncoimmunology 5 e1229725. (doi:10.1080/2162402X.2016.1229725)

Baquero P, Sanchez-Hernandez I, Jimenez-Mora E, Orgaz JL, Jimenez B \& Chiloeches A 2013 (V600E)BRAF promotes invasiveness of thyroid cancer cells by decreasing E-cadherin expression through a Snaildependent mechanism. Cancer Letters 335 232-241. (doi:10.1016/j. canlet.2013.02.033)

Baquero P, Jimenez-Mora E, Santos A, Lasa M \& Chiloeches A 2016 TGFbeta induces epithelial-mesenchymal transition of thyroid cancer cells by both the BRAF/MEK/ERK and Src/FAK pathways. Molecular Carcinogenesis 55 1639-1654. (doi:10.1002/mc.22415)

Bartel DP 2004 MicroRNAs: genomics, biogenesis, mechanism, and function. Cell 116 281-297. (doi:10.1016/S0092-8674(04)00045-5)

Bincoletto C, Bechara A, Pereira GJS, Santos CP, Antunes F, Peixoto da-Silva J, Muler M, Gigli RD, Monteforte PT, Hirata H, et al. 2013 Interplay between apoptosis and autophagy, a challenging puzzle: new perspectives on antitumor chemotherapies. Chemico-Biological Interactions 206 279-288. (doi:10.1016/j.cbi.2013.09.018)

Braun J, Hoang-Vu C, Dralle H \& Huttelmaier S 2010 Downregulation of microRNAs directs the EMT and invasive potential of anaplastic thyroid carcinomas. Oncogene 29 4237-4244. (doi:10.1038/onc.2010.169)

Brose MS, Nutting CM, Jarzab B, Elisei R, Siena S, Bastholt L, de la Fouchardiere C, Pacini F, Paschke R, Shong YK, et al. 2014 Sorafenib in radioactive iodine-refractory, locally advanced or metastatic differentiated thyroid cancer: a randomised, double-blind, phase 3 trial. Lancet 384 319-328. (doi:10.1016/S0140-6736(14)60421-9)

Brose MS, Cabanillas ME, Cohen EE, Wirth LJ, Riehl T, Yue H, Sherman SI \& Sherman EJ 2016 Vemurafenib in patients with BRAF(V600E)-positive metastatic or unresectable papillary thyroid cancer refractory to radioactive iodine: a non-randomised, multicentre, open-label, phase 2 trial. Lancet Oncology 17 1272-1282. (doi:10.1016/S1470-2045(16)30166-8)

Burrows N, Resch J, Cowen RL, von Wasielewski R, Hoang-Vu C, West CM, Williams KJ \& Brabant G 2010 Expression of hypoxiainducible factor 1 alpha in thyroid carcinomas. Endocrine-Related Cancer 17 61-72. (doi:10.1677/ERC-08-0251)

Cabanillas ME, McFadden DG \& Durante C 2016 Thyroid cancer. Lancet 388 2783-2795. (doi:10.1016/S0140-6736(16)30172-6)

Cancer Genome Atlas Research Network 2014 Integrated genomic characterization of papillary thyroid carcinoma. Cell 159 676-690. (doi:10.1016/j.cell.2014.09.050)

Cazarin JM, Coelho RG, Hecht F, Andrade BM \& Carvalho DP 2016 5'-AMP-activated protein kinase regulates papillary (TPC-1 and BCPAP) thyroid cancer cell survival, migration, invasion, and epithelial-to-mesenchymal transition. Thyroid 26 933-942. (doi:10.1089/thy.2015.0440)

Chakravarty D, Santos E, Ryder M, Knauf JA, Liao XH, West BL, Bollag G, Kolesnick R, Thin TH, Rosen N, et al. 2011 Small-molecule MAPK inhibitors restore radioiodine incorporation in mouse thyroid cancers with conditional BRAF activation. Journal of Clinical Investigation 121 4700-4711. (doi:10.1172/JCI46382)

Cheng W, Liu R, Zhu G, Wang H \& Xing M 2016 Robust thyroid gene expression and radioiodine uptake induced by simultaneous suppression of BRAF V600E and histone deacetylase in thyroid cancer cells. Journal of Clinical Endocrinology and Metabolism 101 962-971. (doi:10.1210/jc.2015-3433)

Choi YW, Kim HJ, Kim YH, Park SH, Chwae YJ, Lee J, Soh EY, Kim JH \& Park TJ 2014 B-RafV600E inhibits sodium iodide symporter expression via regulation of DNA methyltransferase 1. Experimental and Molecular Medicine 46 e120. (doi:10.1038/emm.2014.68)

Chou CK, Yang KD, Chou FF, Huang CC, Lan YW, Lee YF, Kang HY \& Liu RT 2013 Prognostic implications of miR-146b expression and its functional role in papillary thyroid carcinoma. Journal of Clinical Endocrinology and Metabolism 98 E196-E205. (doi:10.1210/ jc.2012-2666)

Coclet J, Foureau F, Ketelbant P, Galand P \& Dumont JE 1989 Cell population kinetics in dog and human adult thyroid. Clinical Endocrinology 31 655-665. (doi:10.1111/j.1365-2265.1989. tb01290.x)

Colegio OR, Chu NQ, Szabo AL, Chu T, Rhebergen AM, Jairam V, Cyrus N, Brokowski CE, Eisenbarth SC, Phillips GM, et al. 2014 Functional polarization of tumour-associated macrophages by tumour-derived lactic acid. Nature 513 559-563. (doi:10.1038/ nature13490)

Costamagna E, Garcia B \& Santisteban P 2004 The functional interaction between the paired domain transcription factor Pax8 and Smad3 is involved in transforming growth factor-beta repression of the sodium/iodide symporter gene. Journal of Biological Chemistry 279 3439-3446. (doi:10.1074/jbc.M307138200)

de Araujo-Filho VJ, Alves VA, de Castro IV, Lourenco SV, Cernea CR, Brandao LG \& Ferraz AR 2009 Vascular endothelial growth factor expression in invasive papillary thyroid carcinoma. Thyroid $\mathbf{1 9}$ 1233-1237. (doi:10.1089/thy.2008.0179)

De Bernardi IC, Floridi C, Muollo A, Giacchero R, Dionigi GL, Reginelli A, Gatta G, Cantisani V, Grassi R, Brunese L, et al. 2014 Vascular and interventional radiology radiofrequency ablation of benign thyroid nodules and recurrent thyroid cancers: literature review. La Radiologia Medica 119 512-520. (doi:10.1007/s11547-014-0411-2)

Dettmer M, Perren A, Moch H, Komminoth P, Nikiforov YE \& Nikiforova MN 2013 Comprehensive MicroRNA expression profiling identifies novel markers in follicular variant of papillary thyroid carcinoma. Thyroid 23 1383-1389. (doi:10.1089/ thy.2012.0632)

Duffy A, Le J, Sausville E \& Emadi A 2015 Autophagy modulation: a target for cancer treatment development. Cancer Chemotherapy and Pharmacology 75 439-447. (doi:10.1007/s00280-014-2637-z)

Ekpe-Adewuyi E, Lopez-Campistrous A, Tang X, Brindley DN \& McMullen TP 2016 Platelet derived growth factor receptor alpha mediates nodal metastases in papillary thyroid cancer by driving the epithelial-mesenchymal transition. Oncotarget 7 83684-83700. (doi:10.18632/oncotarget.13299)

Fagin JA \& Wells SA Jr 2016 Biologic and clinical perspectives on thyroid cancer. New England Journal of Medicine 375 1054-1067. (doi:10.1056/NEJMra1501993)

Fagman H \& Nilsson M 2011 Morphogenetics of early thyroid development. Journal of Molecular Endocrinology 46 R33-R42. (doi:10.1677/JME-10-0084)

Fan D, Liu SY, van Hasselt CA, Vlantis AC, Ng EK, Zhang H, Dong Y, Ng SK, Chu R, Chan AB, et al. 2015 Estrogen receptor alpha induces prosurvival autophagy in papillary thyroid cancer via stimulating reactive oxygen species and extracellular signal regulated kinases. Journal of Clinical Endocrinology and Metabolism 100 E561-E571. (doi:10.1210/jc.2014-3257)

Feng Y, Yao Z \& Klionsky DJ 2015 How to control self-digestion: transcriptional, post-transcriptional, and post-translational regulation of autophagy. Trends in Cell Biology 25 354-363. (doi:10.1016/j. tcb.2015.02.002)

Fenton MS, Marion KM, Salem AK, Hogen R, Naeim F \& Hershman JM 2010 Sunitinib inhibits MEK/ERK and SAPK/JNK pathways and increases sodium/iodide symporter expression in papillary thyroid cancer. Thyroid 20 965-974. (doi:10.1089/thy.2010.0008)

Fernandez LP, Lopez-Marquez A \& Santisteban P 2015 Thyroid transcription factors in development, differentiation and disease. Nature Reviews Endocrinology 11 29-42. (doi:10.1038/ nrendo.2014.186)

French JD, Bible K, Spitzweg C, Haugen BR \& Ryder M 2017 Leveraging the immune system to treat advanced thyroid cancers. Lancet Diabetes and Endocrinology 5 469-481. (doi:10.1016/S22138587(16)30277-7)

Published by Bioscientifica Ltd. 
Galdiero MR, Varricchi G \& Marone G 2016 The immune network in thyroid cancer. Oncoimmunology 5 e1168556. (doi:10.1080/21624 02X.2016.1168556)

Garcia-Rostan G, Tallini G, Herrero A, D'Aquila TG, Carcangiu ML \& Rimm DL 1999 Frequent mutation and nuclear localization of betacatenin in anaplastic thyroid carcinoma. Cancer Research 59 1811-1815.

Gatenby RA \& Gillies RJ 2004 Why do cancers have high aerobic glycolysis? Nature Reviews Cancer 4 891-899. (doi:10.1038/nrc1478)

Gewirtz DA 2014 An autophagic switch in the response of tumor cells to radiation and chemotherapy. Biochemical Pharmacology 90 208-211. (doi:10.1016/j.bcp.2014.05.016)

Gibelli B, El-Fattah A, Giugliano G, Proh M \& Grosso E 2009 Thyroid stem cells - danger or resource? Acta Otorhinolaryngologica Italica 29 290-295.

Gill KS, Tassone P, Hamilton J, Hjelm N, Luginbuhl A, Cognetti D, Tuluc M, Martinez-Outschoorn U, Johnson JM \& Curry JM 2016 Thyroid cancer metabolism: a review. Journal of Thyroid Disorders and Therapy 5200.

Gudmundsson J, Sulem P, Gudbjartsson DF, Jonasson JG, Masson G, He H, Jonasdottir A, Sigurdsson A, Stacey SN, Johannsdottir H, et al. 2012 Discovery of common variants associated with low TSH levels and thyroid cancer risk. Nature Genetics 44 319-322. (doi:10.1038/ng.1046)

Gudmundsson J, Thorleifsson G, Sigurdsson JK, Stefansdottir L, Jonasson JG, Gudjonsson SA, Gudbjartsson DF, Masson G, Johannsdottir H, Halldorsson GH, et al. 2017 A genome-wide association study yields five novel thyroid cancer risk loci. Nature Communications 8 14517. (doi:10.1038/ncomms14517)

Gugnoni M, Sancisi V, Gandolfi G, Manzotti G, Ragazzi M, Giordano D, Tamagnini I, Tigano M, Frasoldati A, Piana S, et al. 2017 Cadherin-6 promotes EMT and cancer metastasis by restraining autophagy. Oncogene 36 667-677. (doi:10.1038/onc.2016.237)

Guo Z, Hardin H \& Lloyd RV 2014 Cancer stem-like cells and thyroid cancer. Endocrine-Related Cancer 21 T285-T300. (doi:10.1530/ ERC-14-0002)

Guo Z, Hardin H, Montemayor-Garcia C, Asioli S, Righi A, Maletta F, Sapino A \& Lloyd RV 2015 In situ hybridization analysis of miR146b-5p and miR-21 in thyroid nodules: diagnostic implications. Endocrine Pathology 26 157-163. (doi:10.1007/s12022-015-9363-x)

Han B, Cui H, Kang L, Zhang X, Jin Z, Lu L \& Fan Z 2015 Metformin inhibits thyroid cancer cell growth, migration, and EMT through the mTOR pathway. Tumor Biology 36 6295-6304. (doi:10.1007/s13277015-3315-4)

Hanahan D \& Weinberg RA 2011 Hallmarks of cancer: the next generation. Cell 144 646-674. (doi:10.1016/j.cell.2011.02.013)

Hardin H, Montemayor-Garcia C \& Lloyd RV 2013 Thyroid cancer stemlike cells and epithelial-mesenchymal transition in thyroid cancers. Human Pathology 44 1707-1713. (doi:10.1016/j. humpath.2013.01.009)

Hardin H, Guo Z, Shan W, Montemayor-Garcia C, Asioli S, Yu XM, Harrison AD, Chen H \& Lloyd RV 2014 The roles of the epithelialmesenchymal transition marker PRRX1 and miR-146b-5p in papillary thyroid carcinoma progression. American Journal of Pathology 184 2342-2354. (doi:10.1016/j.ajpath.2014.04.011)

He H, Jazdzewski K, Li W, Liyanarachchi S, Nagy R, Volinia S, Calin GA, Liu CG, Franssila K, Suster S, et al. 2005 The role of microRNA genes in papillary thyroid carcinoma. PNAS $\mathbf{1 0 2}$ 19075-19080. (doi:10.1073/pnas.0509603102)

Heinhuis B, Plantinga TS, Semango G, Kusters B, Netea MG, Dinarello CA, Smit JW, Netea-Maier RT \& Joosten LA 2016 Alternatively spliced isoforms of IL-32 differentially influence cell death pathways in cancer cell lines. Carcinogenesis 37 197-205. (doi:10.1093/carcin/bgv172)

Helgason GV, Holyoake TL \& Ryan KM 2013 Role of autophagy in cancer prevention, development and therapy. Essays in Biochemistry 55 133-151. (doi:10.1042/bse0550133)
Henderson YC, Chen Y, Frederick MJ, Lai SY \& Clayman GL 2010 MEK inhibitor PD0325901 significantly reduces the growth of papillary thyroid carcinoma cells in vitro and in vivo. Molecular Cancer Therapeutics 9 1968-1976. (doi:10.1158/1535-7163.MCT-10-0062)

Ho AL, Grewal RK, Leboeuf R, Sherman EJ, Pfister DG, Deandreis D, Pentlow KS, Zanzonico PB, Haque S, Gavane S, et al. 2013 Selumetinib-enhanced radioiodine uptake in advanced thyroid cancer. New England Journal of Medicine 368 623-632. (doi:10.1056/ NEJMoa1209288)

Hoftijzer H, Heemstra KA, Morreau H, Stokkel MP, Corssmit EP, Gelderblom H, Weijers K, Pereira AM, Huijberts M, Kapiteijn E, et al. 2009 Beneficial effects of sorafenib on tumor progression, but not on radioiodine uptake, in patients with differentiated thyroid carcinoma. European Journal of Endocrinology 161 923-931. (doi:10.1530/EJE-09-0702)

Hoshi N, Kusakabe T, Taylor BJ \& Kimura S 2007 Side population cells in the mouse thyroid exhibit stem/progenitor cell-like characteristics. Endocrinology 148 4251-4258. (doi:10.1210/en.2006-0490)

Hou P, Liu D, Shan Y, Hu S, Studeman K, Condouris S, Wang Y, Trink A, El-Naggar AK, Tallini G, et al. 2007 Genetic alterations and their relationship in the phosphatidylinositol 3-kinase/Akt pathway in thyroid cancer. Clinical Cancer Research 13 1161-1170. (doi:10.1158/1078-0432.CCR-06-1125)

Hou P, Bojdani E \& Xing M 2010 Induction of thyroid gene expression and radioiodine uptake in thyroid cancer cells by targeting major signaling pathways. Journal of Clinical Endocrinology and Metabolism 95 820-828. (doi:10.1210/jc.2009-1888)

Hou P, Liu D \& Xing M 2011 Genome-wide alterations in gene methylation by the BRAF V600E mutation in papillary thyroid cancer cells. Endocrine-Related Cancer 18 687-697. (doi:10.1530/ERC11-0212)

Hu S, Liu D, Tufano RP, Carson KA, Rosenbaum E, Cohen Y, Holt EH, Kiseljak-Vassiliades K, Rhoden KJ, Tolaney S, et al. 2006 Association of aberrant methylation of tumor suppressor genes with tumor aggressiveness and BRAF mutation in papillary thyroid cancer. International Journal of Cancer 119 2322-2329. (doi:10.1002/ ijc.22110)

Huang J \& Guo L 2017 Knockdown of SOX9 inhibits the proliferation, invasion, and EMT in thyroid cancer cells. Oncology Research $\mathbf{2 5}$ 167-176. (doi:10.3727/096504016X14732772150307)

Huijbers A, Plantinga TS, Joosten LA, Aben KK, Gudmundsson J, den Heijer M, Kiemeney LA, Netea MG, Hermus AR \& Netea-Maier RT 2012 The effect of the ATG16L1 Thr300Ala polymorphism on susceptibility and outcome of patients with epithelial cell-derived thyroid carcinoma. Endocrine-Related Cancer 19 L15-L18. (doi:10.1530/ERC-11-0302)

Huillard O, Tenenbaum F, Clerc J, Goldwasser F \& Groussin L 2016 Vemurafenib for BRAFV600E-positive metastatic papillary thyroid cancer. Lancet Oncology 17 e468. (doi:10.1016/S1470-2045(16)30499-5)

Jin SM, Jang HW, Sohn SY, Kim NK, Joung JY, Cho YY, Kim SW \& Chung JH 2014 Role of autophagy in the resistance to tumour necrosis factor-related apoptosis-inducing ligand-induced apoptosis in papillary and anaplastic thyroid cancer cells. Endocrine $\mathbf{4 5}$ 256-262. (doi:10.1007/s12020-013-9997-8)

Jung CW, Han KH, Seol H, Park S, Koh JS, Lee SS, Kim MJ, Choi IJ \& Myung JK 2015 Expression of cancer stem cell markers and epithelial-mesenchymal transition-related factors in anaplastic thyroid carcinoma. International Journal of Clinical and Experimental Pathology 8 560-568.

Kalluri R \& Weinberg RA 2009 The basics of epithelial-mesenchymal transition. Journal of Clinical Investigation 119 1420-1428. (doi:10.1172/JCI39104)

Karaca Z, Tanriverdi F, Unluhizarci K, Ozturk F, Gokahmetoglu S, Elbuken G, Cakir I, Bayram F \& Kelestimur F 2011 VEGFR1 expression is related to lymph node metastasis and serum VEGF may be a marker of progression in the follow-up of patients with 
differentiated thyroid carcinoma. European Journal of Endocrinology 164 277-284. (doi:10.1530/EJE-10-0967)

Kim WG, Kim EY, Kim TY, Ryu JS, Hong SJ, Kim WB \& Shong YK 2009 Redifferentiation therapy with 13-cis retinoic acids in radioiodineresistant thyroid cancer. Endocrine Journal 56 105-112. (doi:10.1507/ endocrj.K08E-254)

Kim S, Cho SW, Min HS, Kim KM, Yeom GJ, Kim EY, Lee KE, Yun YG, Park DJ \& Park YJ 2013 The expression of tumor-associated macrophages in papillary thyroid carcinoma. Endocrinology and Metabolism 28 192-198. (doi:10.3803/EnM.2013.28.3.192)

Kim DI, Kim E, Kim YA, Cho SW, Lim JA \& Park YJ 2016 Macrophage densities correlated with CXC chemokine receptor 4 expression and related with poor survival in anaplastic thyroid cancer. Endocrinology and Metabolism 31 469-475. (doi:10.3803/EnM.2016.31.3.469)

Kimura H, Yamashita S, Namba H, Tominaga T, Tsuruta M, Yokoyama N, Izumi M \& Nagataki S 1992 Interleukin-1 inhibits human thyroid carcinoma cell growth. Journal of Clinical Endocrinology and Metabolism 75 596-602.

Klaus A, Fathi O, Tatjana TW, Bruno N \& Oskar K 2017 Expression of hypoxia-associated protein HIF-1alpha in follicular thyroid cancer is associated with distant metastasis. Pathology and Oncology Research [in press]. (doi:10.1007/s12253-017-0232-4)

Klonisch T, Hoang-Vu C \& Hombach-Klonisch S 2009 Thyroid stem cells and cancer. Thyroid 19 1303-1315. (doi:10.1089/thy.2009.1604)

Knauf JA, Sartor MA, Medvedovic M, Lundsmith E, Ryder M, Salzano M, Nikiforov YE, Giordano TJ, Ghossein RA \& Fagin JA 2011 Progression of BRAF-induced thyroid cancer is associated with epithelialmesenchymal transition requiring concomitant MAP kinase and TGFbeta signaling. Oncogene 30 3153-3162. (doi:10.1038/onc.2011.44)

Koperek O, Akin E, Asari R, Niederle B \& Neuhold N 2013 Expression of hypoxia-inducible factor 1 alpha in papillary thyroid carcinoma is associated with desmoplastic stromal reaction and lymph node metastasis. Virchows Archiv 463 795-802. (doi:10.1007/s00428-0131484-3)

Kumar A, Singh UK \& Chaudhary A 2015 Targeting autophagy to overcome drug resistance in cancer therapy. Future Medicinal Chemistry 7 1535-1542. (doi:10.4155/fmc.15.88)

Lakshmanan A, Wojcicka A, Kotlarek M, Zhang X, Jazdzewski K \& Jhiang SM 2015 microRNA-339-5p modulates Na+/I- symportermediated radioiodide uptake. Endocrine-Related Cancer 22 11-21. (doi:10.1530/ERC-14-0439)

Lan L, Cui D, Nowka K \& Derwahl M 2007 Stem cells derived from goiters in adults form spheres in response to intense growth stimulation and require thyrotropin for differentiation into thyrocytes. Journal of Clinical Endocrinology and Metabolism 92 3681-3688. (doi:10.1210/jc.2007-0281)

Lan L, Luo Y, Cui D, Shi BY, Deng W, Huo LL, Chen HL, Zhang GY \& Deng LL 2013 Epithelial-mesenchymal transition triggers cancer stem cell generation in human thyroid cancer cells. International Journal of Oncology 43 113-120. (doi:10.3892/ijo.2013.1913)

Landa I, Ibrahimpasic T, Boucai L, Sinha R, Knauf JA, Shah RH, Dogan S, Ricarte-Filho JC, Krishnamoorthy GP, Xu B, et al. 2016 Genomic and transcriptomic hallmarks of poorly differentiated and anaplastic thyroid cancers. Journal of Clinical Investigation 126 1052-1066. (doi:10.1172/JCI85271)

Lee JJ, Geli J, Larsson C, Wallin G, Karimi M, Zedenius J, Hoog A \& Foukakis T 2008 Gene-specific promoter hypermethylation without global hypomethylation in follicular thyroid cancer. International Journal of Oncology 33 861-869.

Lee J, Chang JY, Kang YE, Yi S, Lee MH, Joung KH, Kim KS \& Shong M 2015 Mitochondrial energy metabolism and thyroid cancers. Endocrinology and Metabolism 30 117-123. (doi:10.3803/ EnM.2015.30.2.117)

Li L, Lv B, Chen B, Guan M, Sun Y, Li H, Zhang B, Ding C, He S \& Zeng Q 2015 Inhibition of miR-146b expression increases radioiodine-sensitivity in poorly differential thyroid carcinoma via positively regulating NIS expression. Biochemical and Biophysical Research Communications 462 314-321. (doi:10.1016/j. bbrc.2015.04.134)

Li S, Zhang HY, Du ZX, Li C, An MX, Zong ZH, Liu BQ \& Wang HQ 2016 Induction of epithelial-mesenchymal transition (EMT) by Beclin 1 knockdown via posttranscriptional upregulation of ZEB1 in thyroid cancer cells. Oncotarget 7 70364-70377. (doi:10.18632/ oncotarget.12217)

Lim SM, Chang H, Yoon MJ, Hong YK, Kim H, Chung WY, Park CS, Nam KH, Kang SW, Kim MK, et al. 2013 A multicenter, phase II trial of everolimus in locally advanced or metastatic thyroid cancer of all histologic subtypes. Annals of Oncology 24 3089-3094. (doi:10.1093/ annonc/mdt379)

Lin CI, Whang EE, Donner DB, Du J, Lorch J, He F, Jiang X, Price BD, Moore FD Jr \& Ruan DT 2010 Autophagy induction with RAD001 enhances chemosensitivity and radiosensitivity through Met inhibition in papillary thyroid cancer. Molecular Cancer Research $\mathbf{8}$ 1217-1226. (doi:10.1158/1541-7786.MCR-10-0162)

Liotti F, De Pizzol M, Allegretti M, Prevete N \& Melillo RM 2017 Multiple anti-tumor effects of reparixin on thyroid cancer. Oncotarget 8 35946-35961. (doi:10.18632/oncotarget.16412)

Liu J \& Brown RE 2010 Immunohistochemical detection of epithelialmesenchymal transition associated with stemness phenotype in anaplastic thyroid carcinoma. International Journal of Clinical and Experimental Pathology 3 755-762.

Liu YY, van der Pluijm G, Karperien M, Stokkel MP, Pereira AM, Morreau J, Kievit J, Romijn JA \& Smit JW 2006 Lithium as adjuvant to radioiodine therapy in differentiated thyroid carcinoma: clinical and in vitro studies. Clinical Endocrinology 64 617-624. (doi:10.1111/ j.1365-2265.2006.02515.x)

Liu YY, Stokkel MP, Morreau HA, Pereira AM, Romijn JA \& Smit JW 2008 Radioiodine therapy after pretreatment with bexarotene for metastases of differentiated thyroid carcinoma. Clinical Endocrinology 68 605-609. (doi:10.1111/j.1365-2265.2007.03096.x)

Liu R, Liu D \& Xing M 2012 The Akt inhibitor MK2206 synergizes, but perifosine antagonizes, the BRAF(V600E) inhibitor PLX4032 and the MEK1/2 inhibitor AZD6244 in the inhibition of thyroid cancer cells. Journal of Clinical Endocrinology and Metabolism 97 E173-E182. (doi:10.1210/jc.2011-1054)

Liu R, Bishop J, Zhu G, Zhang T, Ladenson PW \& Xing M 2016 Mortality risk stratification by combining BRAF V600E and TERT promoter mutations in papillary thyroid cancer: genetic duet of BRAF and TERT promoter mutations in thyroid cancer mortality. JAMA Oncology [in press]. (doi:10.1001/jamaoncol.2016.3288)

Lunt SY \& Vander Heiden MG 2011 Aerobic glycolysis: meeting the metabolic requirements of cell proliferation. Annual Review of Cell and Developmental Biology 27 441-464. (doi:10.1146/annurevcellbio-092910-154237)

Lv N, Gao Y, Guan H, Wu D, Ding S, Teng W \& Shan Z 2015 Inflammatory mediators, tumor necrosis factor-alpha and interferon-gamma, induce EMT in human PTC cell lines. Oncology Letters 10 2591-2597. (doi:10.3892/ol.2015.3518)

Lv N, Shan Z, Gao Y, Guan H, Fan C, Wang H \& Teng W 2016 Twist1 regulates the epithelial-mesenchymal transition via the NF-kappaB pathway in papillary thyroid carcinoma. Endocrine 51 469-477. (doi:10.1007/s12020-015-0714-7)

Mancikova V, Castelblanco E, Pineiro-Yanez E, Perales-Paton J, de Cubas AA, Inglada-Perez L, Matias-Guiu X, Capel I, Bella M, Lerma E, et al. 2015 MicroRNA deep-sequencing reveals master regulators of follicular and papillary thyroid tumors. Modern Pathology $\mathbf{2 8}$ 748-757. (doi:10.1038/modpathol.2015.44)

Mardente S, Mari E, Consorti F, Di Gioia C, Negri R, Etna M, Zicari A \& Antonaci A 2012 HMGB1 induces the overexpression of miR-222 and miR-221 and increases growth and motility in papillary thyroid cancer cells. Oncology Reports 28 2285-2289. (doi:10.3892/ or.2012.2058) 
Mardente S, Mari E, Massimi I, Fico F, Faggioni A, Pulcinelli F, Antonaci A \& Zicari A 2015 HMGB1-induced cross talk between PTEN and miRs 221/222 in thyroid cancer. BioMed Research International 2015 512027. (doi:10.1155/2015/512027)

Medici M, Porcu E, Pistis G, Teumer A, Brown SJ, Jensen RA, Rawal R, Roef GL, Plantinga TS, Vermeulen SH, et al. 2014 Identification of novel genetic Loci associated with thyroid peroxidase antibodies and clinical thyroid disease. PLoS Genetics 10 e1004123. (doi:10.1371/ journal.pgen.1004123)

Melillo RM, Guarino V, Avilla E, Galdiero MR, Liotti F, Prevete N, Rossi FW, Basolo F, Ugolini C, de Paulis A, et al. 2010 Mast cells have a protumorigenic role in human thyroid cancer. Oncogene $\mathbf{2 9}$ 6203-6215. (doi:10.1038/onc.2010.348)

Melo M, da Rocha AG, Vinagre J, Batista R, Peixoto J, Tavares C, Celestino R, Almeida A, Salgado C, Eloy C, et al. 2014 TERT promoter mutations are a major indicator of poor outcome in differentiated thyroid carcinomas. Journal of Clinical Endocrinology and Metabolism 99 E754-E765. (doi:10.1210/jc.2013-3734)

Mitchell B, Dhingra JK \& Mahalingam M 2016 BRAF and epithelialmesenchymal transition: lessons from papillary thyroid carcinoma and primary cutaneous melanoma. Advances in Anatomic Pathology 23 244-271. (doi:10.1097/PAP.0000000000000113)

Mizushima N \& Komatsu M 2011 Autophagy: renovation of cells and tissues. Cell 147 728-741. (doi:10.1016/j.cell.2011.10.026)

Mizushima N \& Levine B 2010 Autophagy in mammalian development and differentiation. Nature Cell Biology 12 823-830. (doi:10.1038/ ncb0910-823)

Montemayor-Garcia C, Hardin H, Guo Z, Larrain C, Buehler D, Asioli S, Chen H \& Lloyd RV 2013 The role of epithelial mesenchymal transition markers in thyroid carcinoma progression. Endocrine Pathology 24 206-212. (doi:10.1007/s12022-013-9272-9)

Morani F, Titone R, Pagano L, Galetto A, Alabiso O, Aimaretti G \& Isidoro C 2014 Autophagy and thyroid carcinogenesis: genetic and epigenetic links. Endocrine-Related Cancer 21 R13-R29. (doi:10.1530/ ERC-13-0271)

Nagarajah J, Le M, Knauf JA, Ferrandino G, Montero-Conde C, Pillarsetty N, Bolaender A, Irwin C, Krishnamoorthy GP, Saqcena M, et al. 2016 Sustained ERK inhibition maximizes responses of BrafV600E thyroid cancers to radioiodine. Journal of Clinical Investigation 126 4119-4124. (doi:10.1172/JCI89067)

Netea-Maier RT, Kluck V, Plantinga TS \& Smit JWA 2015 Autophagy in thyroid cancer: present knowledge and future perspectives. Frontiers in Endocrinology 6 22. (doi:10.3389/fendo.2015.00022)

Nikiforov YE \& Nikiforova MN 2011 Molecular genetics and diagnosis of thyroid cancer. Nature Reviews Endocrinology 7 569-580. (doi:10.1038/ nrendo.2011.142)

Nikiforova MN, Tseng GC, Steward D, Diorio D \& Nikiforov YE 2008 MicroRNA expression profiling of thyroid tumors: biological significance and diagnostic utility. Journal of Clinical Endocrinology and Metabolism 93 1600-1608. (doi:10.1210/jc.2007-2696)

Nilubol N, Merkel R, Yang L, Patel D, Reynolds JC, Sadowski SM, Neychev V \& Kebebew E 2017 A phase II trial of valproic acid in patients with advanced, radioiodine-resistant thyroid cancers of follicular cell origin. Clinical Endocrinology 86 128-133. (doi:10.1111/ cen.13154)

Ohta K, Pang XP, Berg L \& Hershman JM 1996 Antitumor actions of cytokines on new human papillary thyroid carcinoma cell lines. Journal of Clinical Endocrinology and Metabolism 81 2607-2612.

Pacini F, Castagna MG, Brilli L, Pentheroudakis G \& Group EGW 2012 Thyroid cancer: ESMO Clinical Practice Guidelines for diagnosis, treatment and follow-up. Annals of Oncology 23 (Supplement 7) vii110-vii119. (doi:10.1093/annonc/mds230)

Pallante P, Visone R, Ferracin M, Ferraro A, Berlingieri MT, Troncone G, Chiappetta G, Liu CG, Santoro M, Negrini M, et al. 2006 MicroRNA deregulation in human thyroid papillary carcinomas. EndocrineRelated Cancer 13 497-508. (doi:10.1677/erc.1.01209)
Petrulea MS, Plantinga TS, Smit JW, Georgescu CE \& Netea-Maier RT 2015 PI3K/Akt/mTOR: a promising therapeutic target for nonmedullary thyroid carcinoma. Cancer Treatment Reviews 41 707-713. (doi:10.1016/j.ctrv.2015.06.005)

Plantinga TS, Costantini I, Heinhuis B, Huijbers A, Semango G, Kusters B, Netea MG, Hermus AR, Smit JW, Dinarello CA, et al. 2013 A promoter polymorphism in human interleukin-32 modulates its expression and influences the risk and the outcome of epithelial cellderived thyroid carcinoma. Carcinogenesis 34 1529-1535. (doi:10.1093/carcin/bgt092)

Plantinga TS, Heinhuis B, Gerrits D, Netea MG, Joosten LAB, Hermus ARMM, Oyen WJG, Schweppe RE, Haugen BR, Boerman OC, et al. 2014a mTOR Inhibition promotes TTF1-dependent redifferentiation and restores iodine uptake in thyroid carcinoma cell lines. Journal of Clinical Endocrinology and Metabolism 99 E1368-E1375. (doi:10.1210/jc.2014-1171)

Plantinga TS, van de Vosse E, Huijbers A, Netea MG, Joosten LA, Smit JW \& Netea-Maier RT 2014b Role of genetic variants of autophagy genes in susceptibility for non-medullary thyroid cancer and patients outcome. PLoS ONE 9 e94086. (doi:10.1371/journal. pone.0094086)

Plantinga TS, Tesselaar MH, Morreau H, Corssmit EP, Willemsen BK, Kusters B, van Engen-van Grunsven AC, Smit JW \& Netea-Maier RT 2016 Autophagy activity is associated with membranous sodium iodide symporter expression and clinical response to radioiodine therapy in non-medullary thyroid cancer. Autophagy 12 1195-1205. (doi:10.1080/15548627.2016.1174802)

Plantinga TS, Petrulea MS, Oosting M, Joosten LAB, Piciu D, Smit JW, Netea-Maier RT \& Georgescu CE 2017 Association of NF-kappaB polymorphisms with clinical outcome of non-medullary thyroid carcinoma. Endocrine-Related Cancer 24 307-318. (doi:10.1530/ERC17-0033)

Plews RL, Mohd Yusof A, Wang C, Saji M, Zhang X, Chen CS, Ringel MD \& Phay JE 2015 A novel dual AMPK activator/mTOR inhibitor inhibits thyroid cancer cell growth. Journal of Clinical Endocrinology and Metabolism 100 E748-E756. (doi:10.1210/jc.2014-1777)

Prassas I \& Diamandis EP 2008 Novel therapeutic applications of cardiac glycosides. Nature Reviews Drug Discovery 7 926-935. (doi:10.1038/ nrd2682)

Read ML, Lewy GD, Fong JC, Sharma N, Seed RI, Smith VE, Gentilin E, Warfield A, Eggo MC, Knauf JA, et al. 2011 Proto-oncogene PBF/ PTTG1IP regulates thyroid cell growth and represses radioiodide treatment. Cancer Research 71 6153-6164. (doi:10.1158/0008-5472. CAN-11-0720)

Read ML, Fong JC, Modasia B, Fletcher A, Imruetaicharoenchoke W, Thompson RJ, Nieto H, Reynolds JJ, Bacon A, Mallick U, et al. 2017 Elevated PTTG and PBF predicts poor patient outcome and modulates DNA damage response genes in thyroid cancer. Oncogene 36 5296-5308. (doi:10.1038/onc.2017.154)

Riesco-Eizaguirre G, Rodriguez I, De la Vieja A, Costamagna E, Carrasco N, Nistal M \& Santisteban P 2009 The BRAFV600E oncogene induces transforming growth factor beta secretion leading to sodium iodide symporter repression and increased malignancy in thyroid cancer. Cancer Research 69 8317-8325. (doi:10.1158/00085472.CAN-09-1248)

Riesco-Eizaguirre G, Wert-Lamas L, Perales-Paton J, Sastre-Perona A, Fernandez LP \& Santisteban P 2015 The miR-146b-3p/PAX8/NIS regulatory circuit modulates the differentiation phenotype and function of thyroid cells during carcinogenesis. Cancer Research $\mathbf{7 5}$ 4119-4130. (doi:10.1158/0008-5472.CAN-14-3547)

Rodriguez-Rodero S, Fernandez AF, Fernandez-Morera JL, Castro-Santos P, Bayon GF, Ferrero C, Urdinguio RG, Gonzalez-Marquez R, Suarez C, Fernandez-Vega I, et al. 2013 DNA methylation signatures identify biologically distinct thyroid cancer subtypes. Journal of Clinical Endocrinology and Metabolism 98 2811-2821. (doi:10.1210/ jc.2012-3566)

Published by Bioscientifica Ltd. 
Romesser PB, Sherman EJ, Shaha AR, Lian M, Wong RJ, Sabra M, Rao SS Fagin JA, Tuttle RM \& Lee NY 2014 External beam radiotherapy with or without concurrent chemotherapy in advanced or recurrent nonanaplastic non-medullary thyroid cancer. Journal of Surgical Oncology 110 375-382. (doi:10.1002/jso.23656)

Rosenbaum-Krumme SJ, Bockisch A \& Nagarajah J 2012a Pioglitazone therapy in progressive differentiated thyroid carcinoma. Nuklearmedizin 51 111-115. (doi:10.3413/Nukmed-0474-12-01)

Rosenbaum-Krumme SJ, Freudenberg LS, Jentzen W, Bockisch A \& Nagarajah J 2012b Effects of rosiglitazone on radioiodine negative and progressive differentiated thyroid carcinoma as assessed by (1)(2) (4)I PET/CT imaging. Clinical Nuclear Medicine 37 e47-e52. (doi:10.1097/RLU.0b013e3182443ca6)

Rossing M, Borup R, Henao R, Winther O, Vikesaa J, Niazi O, Godballe C, Krogdahl A, Glud M, Hjort-Sorensen C, et al. 2012 Down-regulation of microRNAs controlling tumourigenic factors in follicular thyroid carcinoma. Journal of Molecular Endocrinology $\mathbf{4 8}$ 11-23. (doi:10.1530/JME-11-0039)

Rothenberg SM, McFadden DG, Palmer EL, Daniels GH \& Wirth LJ 2015 Redifferentiation of iodine-refractory BRAF V600E-mutant metastatic papillary thyroid cancer with dabrafenib. Clinical Cancer Research 21 1028-1035. (doi:10.1158/1078-0432.CCR-14-2915)

Rupaimoole R \& Slack FJ 2017 MicroRNA therapeutics: towards a new era for the management of cancer and other diseases. Nature Reviews Drug Discovery 16 203-222. (doi:10.1038/nrd.2016.246)

Ryder M, Ghossein RA, Ricarte-Filho JC, Knauf JA \& Fagin JA 2008 Increased density of tumor-associated macrophages is associated with decreased survival in advanced thyroid cancer. Endocrine-Related Cancer 15 1069-1074. (doi:10.1677/ERC-08-0036)

Ryder M, Gild M, Hohl TM, Pamer E, Knauf J, Ghossein R, Joyce JA \& Fagin JA 2013 Genetic and pharmacological targeting of CSF-1/ CSF-1R inhibits tumor-associated macrophages and impairs BRAFinduced thyroid cancer progression. PLoS One 8 e54302. (doi:10.1371/journal.pone.0054302)

San-Millan I \& Brooks GA 2017 Reexamining cancer metabolism: lactate production for carcinogenesis could be the purpose and explanation of the Warburg Effect. Carcinogenesis 38 119-133. (doi:10.1093/ carcin/bgw127)

Santarpia L, El-Naggar AK, Cote GJ, Myers JN \& Sherman SI 2008 Phosphatidylinositol 3-kinase/akt and ras/raf-mitogen-activated protein kinase pathway mutations in anaplastic thyroid cancer. Journal of Clinical Endocrinology and Metabolism 93 278-284. (doi:10.1210/jc.2007-1076)

Sassa M, Hayashi Y, Watanabe R, Kikumori T, Imai T, Kurebayashi J, Kiuchi T \& Murata Y 2011 Aberrant promoter methylation in overexpression of CITED1 in papillary thyroid cancer. Thyroid $\mathbf{2 1}$ 511-517. (doi:10.1089/thy.2010.0295)

Scarpino S, Cancellario d'Alena F, Di Napoli A, Pasquini A, Marzullo A \& Ruco LP 2004 Increased expression of Met protein is associated with up-regulation of hypoxia inducible factor-1 (HIF-1) in tumour cells in papillary carcinoma of the thyroid. Journal of Pathology $\mathbf{2 0 2}$ 352-358. (doi:10.1002/path.1522)

Schneider TC, de Wit D, Links TP, van Erp NP, van der Hoeven JJ, Gelderblom H, Roozen IC, Bos M, Corver WE, van Wezel T, et al. 2017 Everolimus in patients with advanced follicular-derived thyroid cancer: results of a phase II clinical trial. Journal of Clinical Endocrinology and Metabolism 102 698-707. (doi:10.1210/ jc.2016-2525)

Sherman EJ, Dunn LA, Ho AL, Baxi SS, Ghossein RA, Fury MG, Haque S, Sima CS, Cullen G, Fagin JA, et al. 2017 Phase 2 study evaluating the combination of sorafenib and temsirolimus in the treatment of radioactive iodine-refractory thyroid cancer. Cancer [in press]. (doi:10.1002/cncr.30861)

Smallridge RC, Ain KB, Asa SL, Bible KC, Brierley JD, Burman KD, Kebebew E, Lee NY, Nikiforov YE, Rosenthal MS, et al. 2012 American Thyroid Association guidelines for management of patients with anaplastic thyroid cancer. Thyroid 22 1104-1139. (doi:10.1089/thy.2012.0302)

Sondermann A, Andreghetto FM, Moulatlet AC, da Silva Victor E, de Castro MG, Nunes FD, Brandao LG \& Severino P 2015 MiR-9 and miR-21 as prognostic biomarkers for recurrence in papillary thyroid cancer. Clinical and Experimental Metastasis 32 521-530. (doi:10.1007/ s10585-015-9724-3)

Swierniak M, Wojcicka A, Czetwertynska M, Stachlewska E, Maciag M, Wiechno W, Gornicka B, Bogdanska M, Koperski L, de la Chapelle A, et al. 2013 In-depth characterization of the microRNA transcriptome in normal thyroid and papillary thyroid carcinoma. Journal of Clinical Endocrinology and Metabolism 98 E1401-E1409. (doi:10.1210/ jc.2013-1214)

Takano T 2014 Fetal cell carcinogenesis of the thyroid: a modified theory based on recent evidence. Endocrine Journal 61 311-320. (doi:10.1507/endocrj.EJ13-0517)

Takano T \& Amino N 2005 Fetal cell carcinogenesis: a new hypothesis for better understanding of thyroid carcinoma. Thyroid 15 432-438. (doi:10.1089/thy.2005.15.432)

Tesselaar MH, Crezee T, Swarts HG, Gerrits D, Boerman OC, Koenderink JB, Stunnenberg HG, Netea MG, Smit JW, NeteaMaier RT, et al. 2017 Digitalis-like compounds facilitate nonmedullary thyroid cancer redifferentiation through intracellular Ca2+, FOS, and autophagy-dependent pathways. Molecular Cancer Therapeutics 16 169-181. (doi:10.1158/1535-7163.MCT-16-0460)

Tetzlaff MT, Liu A, Xu X, Master SR, Baldwin DA, Tobias JW, Livolsi VA \& Baloch ZW 2007 Differential expression of miRNAs in papillary thyroid carcinoma compared to multinodular goiter using formalin fixed paraffin embedded tissues. Endocrine Pathology 18 163-173. (doi:10.1007/s12022-007-0023-7)

Todaro M, Iovino F, Eterno V, Cammareri P, Gambara G, Espina V, Gulotta G, Dieli F, Giordano S, De Maria R, et al. 2010 Tumorigenic and metastatic activity of human thyroid cancer stem cells. Cancer Research 70 8874-8885. (doi:10.1158/0008-5472.CAN-10-1994)

Vasko V, Espinosa AV, Scouten W, He H, Auer H, Liyanarachchi S, Larin A, Savchenko V, Francis GL, de la Chapelle A, et al. 2007 Gene expression and functional evidence of epithelial-to-mesenchymal transition in papillary thyroid carcinoma invasion. PNAS $\mathbf{1 0 4}$ 2803-2808. (doi:10.1073/pnas.0610733104)

Visciano C, Liotti F, Prevete N, Cali G, Franco R, Collina F, de Paulis A, Marone G, Santoro M \& Melillo RM 2015 Mast cells induce epithelial-to-mesenchymal transition and stem cell features in human thyroid cancer cells through an IL-8-Akt-Slug pathway. Oncogene 34 5175-5186. (doi:10.1038/onc.2014.441)

Wagle N, Grabiner BC, Van Allen EM, Amin-Mansour A, TaylorWeiner A, Rosenberg M, Gray N, Barletta JA, Guo Y, Swanson SJ, et al. 2014 Response and acquired resistance to everolimus in anaplastic thyroid cancer. New England Journal of Medicine $\mathbf{3 7 1}$ 1426-1433. (doi:10.1056/NEJMoa1403352)

Wang N, Luo HJ, Yin GB, Dong CR, Xu M, Chen GG \& Liu ZM 2013 Overexpression of HIF-2alpha, TWIST, and CXCR4 is associated with lymph node metastasis in papillary thyroid carcinoma. Clinical and Developmental Immunology 2013589423. (doi:10.1155/2013/413928)

Wang N, Dong CR, Jiang R, Tang C, Yang L, Jiang QF, Chen GG \& Liu ZM 2014 Overexpression of HIF-1alpha, metallothionein and SLUG is associated with high TNM stage and lymph node metastasis in papillary thyroid carcinoma. International Journal of Clinical and Experimental Pathology 7 322-330.

Wang W, Kang H, Zhao Y, Min I, Wyrwas B, Moore M, Teng L, Zarnegar R, Jiang X \& Fahey TJ 3rd2017 Targeting autophagy sensitizes BRAF-mutant thyroid cancer to vemurafenib. Journal of Clinical Endocrinology and Metabolism 102 634-643. (doi:10.1210/ jc.2016-1999)

Xing M 2007 Gene methylation in thyroid tumorigenesis. Endocrinology 148 948-953. (doi:10.1210/en.2006-0927) 
Xing M 2013 Molecular pathogenesis and mechanisms of thyroid cancer. Nature Reviews Cancer 13 184-199. (doi:10.1038/nrc3431)

Yamashita S, Kimura H, Ashizawa K, Nagayama Y, Hirayu H, Izumi M \& Nagataki S 1989 Interleukin-1 inhibits thyrotrophin-induced human thyroglobulin gene expression. Journal of Endocrinology 122 177-183. (doi:10.1677/joe.0.1220177)

Yang YJ, Na HJ, Suh MJ, Ban MJ, Byeon HK, Kim WS, Kim JW, Choi EC, Kwon HJ, Chang JW, et al. 2015 Hypoxia induces epithelial-mesenchymal transition in follicular thyroid cancer: involvement of regulation of twist by hypoxia inducible factor1alpha. Yonsei Medical Journal 56 1503-1514. (doi:10.3349/ ymj.2015.56.6.1503)

Yang X, Li J, Li X, Liang Z, Gao W, Liang J, Cheng S \& Lin Y 2017 TERT promoter mutation predicts radioiodine-refractory character in distant metastatic differentiated thyroid cancer. Journal of Nuclear Medicine $\mathbf{5 8}$ 258-265. (doi:10.2967/ jnumed.116.180240)

Yi H, Long B, Ye X, Zhang L, Liu X \& Zhang C 2014 Autophagy: a potential target for thyroid cancer therapy (review). Molecular and Clinical Oncology 2 661-665. (doi:10.3892/mco.2014.305)

Yoo SK, Lee S, Kim SJ, Jee HG, Kim BA, Cho H, Song YS, Cho SW, Won JK, Shin JY, et al. 2016 Comprehensive analysis of the transcriptional and mutational landscape of follicular and papillary thyroid cancers. PLoS Genetics 12 e1006239. (doi:10.1371/journal. pgen.1006239)

Zane M, Scavo E, Catalano V, Bonanno M, Todaro M, De Maria R \& Stassi G 2016 Normal vs cancer thyroid stem cells: the road to transformation. Oncogene 35 805-815. (doi:10.1038/onc.2015.138)

Zhang P, Zuo H, Nakamura Y, Nakamura M, Wakasa T \& Kakudo K 2006 Immunohistochemical analysis of thyroid-specific transcription factors in thyroid tumors. Pathology International 56 240-245. (doi:10.1111/j.1440-1827.2006.01959.x)

Zhang Z, Liu D, Murugan AK, Liu Z \& Xing M 2014 Histone deacetylation of NIS promoter underlies BRAF V600E-promoted NIS silencing in thyroid cancer. Endocrine-Related Cancer 21 161-173. (doi:10.1530/ERC-13-0399)

Zhong J, Liu C, Zhang QH, Chen L, Shen YY, Chen YJ, Zeng X, Zu XY \& Cao RX 2017 TGF-beta1 induces HMGA1 expression: the role of HMGA1 in thyroid cancer proliferation and invasion. International Journal of Oncology 50 1567-1578. (doi:10.3892/ijo.2017.3958)

Zuo H, Gandhi M, Edreira MM, Hochbaum D, Nimgaonkar VL, Zhang P, Dipaola J, Evdokimova V, Altschuler DL \& Nikiforov YE 2010 Downregulation of Rap1GAP through epigenetic silencing and loss of heterozygosity promotes invasion and progression of thyroid tumors. Cancer Research 70 1389-1397. (doi:10.1158/0008-5472. CAN-09-2812)

Received in final form 12 September 2017

Accepted 20 September 2017

Accepted Preprint published online 20 September 2017
() 2017 Society for Endocrinology Printed in Great Britain
Published by Bioscientifica Ltd. 